\title{
On the future of the giant South American river turtle Podocnemis expansa
}

\author{
German Forero-Medina, Camila R. Ferrara, Richard C. Vogt \\ Camila K. Fagundes, Rafael Antônio M. Balestra, Paulo C. M. Andrade \\ Roberto Lacava, Rafael Bernhard, Alison J. Lipman, Ana Julia Lenz \\ Arnaldo Ferrer, Arsenio Calle, Andres F. Aponte \\ Bayron R. Calle-Rendón, Cássia Santos Camilo, Elis Perrone \\ Esteban Miraña, Fabio A. G. Cunha, Eva Loja, Jennifer Del Rio \\ Jorge Luiz Vera Fernandez, Omar E. Hermández, Rafael Del Aguila \\ Rafael Pino, Ruben Cueva, Sindy Martinez \\ Virgínia Campos Diniz Bernardes, Lila Sainz and Brian D. Horne
}

\begin{abstract}
There is a long history of exploitation of the South American river turtle Podocnemis expansa. Conservation efforts for this species started in the 1960 s but best practices were not established, and population trends and the number of nesting females protected remained unknown. In 2014 we formed a working group to discuss conservation strategies and to compile population data across the species' range. We analysed the spatial pattern of its abundance in relation to human and natural factors using multiple regression analyses. We found that $>85$ conservation programmes are protecting 147,000 nesting females, primarily in Brazil. The top six sites harbour $>100,000$ females and should be prioritized for conservation action. Abundance declines with latitude and
\end{abstract}

German Forero-Medina (Corresponding author) Wildlife Conservation Society/Turtle Survival Alliance, Avenida 5N \# 22-11, Cali, Colombia E-mail gforero@wcs.org

Camila R. Ferrara and Camila K. Fagundes Wildlife Conservation Society, Manaus, Brazil

Richard C. Vogt, Virginia Campos Diniz Bernardes and Fabio A. G. Cunha Associação de Ictiólogos e Herpetólogos da Amazônia, Instituto Nacional de Pesquisas da Amazônia, Manaus, Brazil

Rafael Antônio M. Balestra Instituto Chico Mendes de Conservação da Biodiversidade, Centro Nacional de Pesquisa e Conservação de Répteis e Anfíbios, Goiânia, Brazil

Paulo C. M. Andrade Universidade Federal do Amazonas, Projeto Pé-dePincha, Manaus, Brazil

Roberto LaCAVA Instituto Brasileiro do Meio Ambiente e dos Recursos Naturais Renováveis, Brasília, Brazil

Rafael Bernhard Universidade do Estado do Amazonas, Tefé, Brazil

ALISON J. LIPMAN Selva International/UCLA, Los Angeles, USA

Ana Julia Lenz Instituto de Desenvolvimento Sustentável Mamirauá, Tefé, Brazil

Arnaldo FerRer Fundacion la Salle, Caracas, Venezuela

ARsenio Calle Servicio Nacional de Áreas Naturales Protegidas, Parque Nacional Alto Purús, Lima, Perú

Andres F. Aponte Fundación Biodiversa Colombia, Bogotá, Colombia

Received 12 April 2018. Revision requested 24 July 2018.

Accepted 6 November 2018. First published online 25 June 2019. we found no evidence of human pressure on current turtle abundance patterns. It is presently not possible to estimate the global population trend because the species is not monitored continuously across the Amazon basin. The number of females is increasing at some localities and decreasing at others. However, the current size of the protected population is well below the historical population size estimated from past levels of human consumption, which demonstrates the need for concerted global conservation action. The data and management recommendations compiled here provide the basis for a regional monitoring programme among South American countries.

Keywords Amazon basin, conservation, freshwater turtles, giant South American river turtle, head-starting, management, monitoring, Podocnemis expansa

Bayron R. Calle-Rendón and Esteban Miraña $†$ Parque Nacional Natural Cahuinarí, Parques Nacionales Naturales de Colombia, Leticia, Colombia

Cássia Santos Camilo* Universidade do Estado do Amazonas, Tefé, Brazil

Elis Perrone (iD) orcid.org/0000-0002-5450-3928) Programa de PósGraduação em Biodiversidade Tropical, Universidade Federal do Amapá, Macapa, Brazil

Eva Loja Servicio Nacional de Áreas Naturales Protegidas, Reserva Nacional Pacaya Samiria, Lima, Perú

Jennifer Del Rio Fundación Pedregoza, Bogotá, Colombia

Jorge Luiz Vera Fernandez Ministerio de Medio Ambiente, Quito, Ecuador

Omar E. Hermández Fundación para el Desarrollo de Ciencias Físicas, Matemáticas y Naturales, Caracas, Venezuela

Rafael Del Aguila ECOPURUS, Pucalpa, Peru

Rafael Pino Servicio Nacional de Áreas Naturales Protegidas, Reserva Comunal de Purús, Lima, Peru

Ruben Cueva Wildlife Conservation Society, Quito, Ecuador

Sindy Martinez Fundación Omacha, Bogotá, Colombia

Lila Sainz World Wildlife Fund, La Paz, Bolivia

Brian D. Horne Wildlife Conservation Society, New York, USA

*Also at: University of Florida, Gainesville, USA

$\dagger$ Also at: Asociación PANI, Rio Caquetá, Colombia 
Supplementary material for this article is available at https://doi.org/10.1017/So030605318001370

\section{Introduction}

F reshwater turtles play important roles in ecosystems through their large standing crop biomass, high secondary productivity, and contribution to energy flow within and between ecosystems (Lovich et al., 2018). They are also an important food resource for human riverine communities (Vogt, 2008), but overexploitation has diminished their populations. Neotropical river turtles of the genus Podocnemis are no exception, with all species considered threatened (Turtle Taxonomy Working Group, 2017). In particular, there is an extensive history of exploitation of the Giant South American river turtle Podocnemis expansa (Bates, 1892; Smith, 1974). The species occurs over a vast area in the Orinoco and Amazon Rivers across eight countries (Vogt, 2008). When humans settled along these rivers, turtles became a valuable source of food and income. Although Indigenous Peoples had used turtles in the Amazon as a source of protein for a long time, large-scale commercialization of turtles and their eggs began only after the arrival of Europeans (Bates, 1892; Smith, 1974; Vogt, 2008). The unsustainable harvest of eggs and meat has resulted in depleted populations across the species' range (Bates, 1892; Klemens \& Thorbjarnarson, 1995). Podocnemis expansa is currently categorized as Lower Risk/Conservation Dependent on the IUCN Red List (Tortoise \& Freshwater Specialist Group, 1996), but categorization as Critically Endangered has been recommended by the Turtle Taxonomy Working Group (2017).

In the regions of the upper Amazon, Solimões and Madeira Rivers in the state of Amazonas, Brazil, during 1848-1859, 48 million eggs and the fat from adult turtles were rendered for lighting the streets of Manaus and for cooking oil, much of which was sent to Europe (Bates, 1892; Smith, 1979). In Peru, Paul Marcoy (1873) recorded that the Indigenous People from the Ucayali River could capture up to 1,000 turtles in one night, of which c. 300 were consumed or traded with European missionaries, and the remaining turtles were killed to extract their fat and eggs. Another example comes from the Middle Orinoco River in Venezuela, where the population dropped from $>330,000$ in 1800 (Humboldt, 1820 ), to 123,622 in 1945 (Ojasti, 1967) and to 700-1,300 (MINAMB, 2002) in 2010 (Mogollones et al., 2010). Although these estimates relied on different sampling methods and are therefore not directly comparable, they indicate a significant decline in the Orinoco River population (Mogollones et al., 2010).

Multiple attempts have been made to reduce trade of the species, but hunting pressure is still high. One conservative analysis in the Brazilian Amazon suggested that in the 1980 os and 1990s, 59,149-145,019 adult $P$. expansa were consumed annually by low-income rural communities (Peres, 2000). In the city of Tapauá in the state of Amazonas, Brazil, with a human population of no more than 18,000 , an estimated 35 tonnes (26,00o turtles, all species) were consumed per year during 2006-2007 (Pantoja-Lima et al., 2014).

Many communities, biologists and governmental organizations have implemented conservation activities for $P$. expansa, with the first attempts to manage and protect the species in situ starting in the 1960s. These initiatives have grown in number over the years, and at least one river turtle conservation programme can be found in every country across the species' range. The projects' main objective is to protect nesting beaches, with the aim of reducing egg and hatchling mortality, but few have invested in monitoring to evaluate the effectiveness of their actions. As a result, only few long-term population studies have been published for the giant river turtle (Hernández \& Espin, 2006; Mogollones et al., 2010; Peñaloza et al., 2013; Portelinha et al., 2014). However, the high number of existing conservation projects represents an opportunity for building collaborations, learning from successes and failures, monitoring the species across its range, understanding global trends, and raising funds to address threats. In this context, researchers and conservationists working in the Amazon gathered in 2014, for the first time, to share their approaches and discuss best practices for the species' conservation. The data shared by the group enabled the first assessment of conservation projects and the first estimation of the global number of reproductive females under protection or management. Here we present the results of this assessment and analyse the current abundance patterns of the species. We also make management recommendations regarding beach protection, population monitoring, and head-starting, the practice of rearing hatchlings in captivity during their early months to a size that makes them less vulnerable to natural predation (Moll \& Moll, 2004; Burke, 2015).

\section{Methods}

Nesting females under protection and population trends

A group of researchers and conservation practitioners from six countries across the Orinoco and Amazon Basins gathered in Balbina, Brazil, in April 2014 to compile data and discuss the current state and future of the giant South American river turtle. We gathered information on the number and location of conservation sites and the number of nesting females at each site. We used the number of nests at each site as a proxy for the number of nesting females, as the species nests once a year (Vogt, 2008). Based on this information we estimated the global number of nesting 
females under protection or management, considering data from the most recent nesting season in each case, ranging from 2012 to 2014. Additionally, we evaluated the trends in number of reproductive females for some Brazilian rivers that are monitored by federal government and for which this information was available (Projeto Quelônios da Amazônia; IBAMA, unpubl. data). We plotted the trend in number of hatchlings in each river, using a simple moving average of orders $3-5$ to separate the trend component from the irregular component. We then used linear regressions to test whether the number of hatchlings varied over time in each river, evaluating whether the slope was significantly different from zero. Based on the population data, we also developed a set of recommendations for the conservation and monitoring of the species. We evaluated three specific topics: (1) protection of adult females and nesting beaches, (2) monitoring and population studies, and (3) headstarting. For each topic we develop a set of recommended best practices based on the available evidence and the experience of researchers and practitioners.

\section{Abundance patterns}

We evaluated if the spatial pattern of current numbers of nesting females is related to human factors or natural conditions, using multiple regression analyses. Firstly, we conducted an analysis using data from seven countries across the basin, in which the number of nesting females was the response variable, and predictive variables included latitude and longitude (natural patterns), human population density and distance to the closest city by river (human factors). Human population density values for each site were extracted from the WorldPop continental dataset for America (WorldPop, 2010) and correspond to the number of persons per $\mathrm{km}^{2}$ in 2010. Distance to the closest city was estimated using path distance, with rivers designated as the only possible routes between nesting beaches and the closest city. Because data on population and municipality income were available at a higher resolution for Brazil, we conducted a second analysis for locations in Brazil only ( $n=69,81 \%$ of the nesting beaches), in which we also evaluated the GDP (gross domestic product) and total population of each municipality as predictor variables (IBGE, 2010). We expected human population size and income to be negatively and positively related to the species' abundance, respectively. We used the natural logarithm of the dependent, to correct for non-homoscedasticity.

\section{Results}

Nesting females under protection and population trends

There are at least 89 sites across the Amazon and Orinoco Basins where conservation programmes are currently implementing monitoring and conservation actions for $P$. expansa (Fig. 1, Supplementary Table 1). Programmes are run by governments, national park systems, rural or Indigenous communities, and NGOs. Some of these programmes were started $>40$ years ago, and most of the actions implemented by these initiatives include beach protection during the nesting season, environmental education, and head-starting of hatchlings, the latter being reported by at least 21 programmes.

We estimated there are c. 147,000 females of $P$. expansa across six Amazon countries (Brazil, Colombia, Bolivia, Peru, Venezuela, and Ecuador; Fig. 1, Table 1) that are being protected, managed or monitored. Brazil has the largest number of reported nesting females $(>75 \%$ of the protected populations). Rivers such as the Guaporé and the Tapajos in Brazil are important nesting areas, with $>30,000$ and $>10,000$ nesting females, respectively. The population at the Iténez Reserve (Beni Department), on the Guaporé (Iténez) River in Bolivia, is the largest protected population outside Brazil (30,000 nesting females). Analysis of the trends in number of nesting females in the Brazilian rivers monitored by Projeto Quelônios da Amazônia suggest that some populations are declining, although others appear to be stable or increasing (Fig. 2). Of the nine areas monitored, populations in at least three river basins (Trombetas, Javaés and Rio Branco) appear to be decreasing, four suggest positive trends (Tapajós, Guaporé, Foz do Amazonas, Purus), and for the other two there is no evidence of a significant trend (Table 2). It is currently not possible to evaluate the overall trend across the Amazon basin because many of the programmes have not been collecting data for $>20$ years, as required to reliably evaluate population trends.

\section{Abundance patterns}

The multiple regression model that included data from all countries showed that only latitude had a significant negative partial effect on the number of nesting females, with higher latitudes corresponding to fewer nesting females $\left(F_{(4.77)}=5.73 ; \mathrm{P}<0.001\right.$; adjusted $R^{2}=0.19$; Table 3$)$. None of the other variables had a significant effect on the number of females.

The analysis for locations within Brazil had a similar result, again only latitude had a significant, negative partial effect on the number of nesting females $\left(F_{(6.62)}=6.07\right.$; $\mathrm{P}<0.001$; adjusted $\left.R^{2}=0.31\right)$. We found no correlation between the variables representing human pressure (population density, distance to human settlements, income) and turtle abundance patterns.

\section{Discussion}

Although there are many conservation projects for P. expan$s a$ across its range, not all of them have been monitoring 


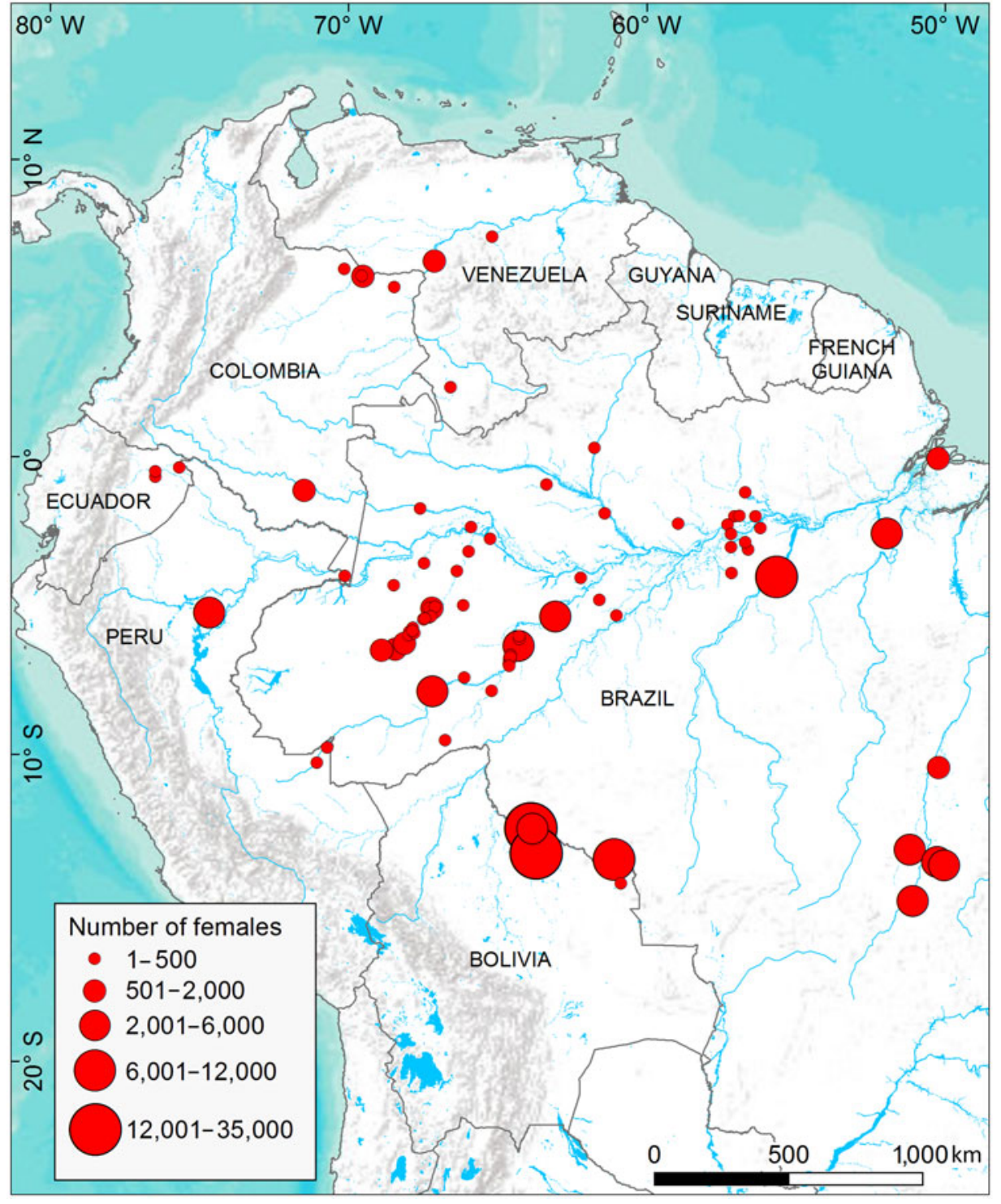

FIG. 1 Sites with ongoing conservation or monitoring activities for the giant river turtle Podocnemis expansa in the Amazon and Orinoco River basin, indicating the number of reproductive females estimated for each site. The size of the dots corresponds to the number of nesting females at each site.
TABLE 1 Number of reproductive females (estimated from number of nests) of the giant river turtle Podocnemis expansa under conservation or management in 2014 across the species' global range.

\begin{tabular}{lcl}
\hline Country & $\begin{array}{l}\text { Number of females under } \\
\text { protection in 2012-2014 }\end{array}$ & $\begin{array}{l}\text { Year first pro- } \\
\text { gramme started }\end{array}$ \\
\hline Ecuador & 6 & 1992 \\
Peru & 4,141 & 1985 \\
Venezuela & 1,043 & 2007 \\
Colombia & 2,428 & 1987 \\
Bolivia & 30,089 & 2007 \\
Brazil & 109,473 & 1967 \\
Total & 147,180 & \\
\hline
\end{tabular}

their populations, and only a few have published population estimates (Hernández \& Espin, 2006; Mogollones et al., 2010; Peñaloza et al., 2013). For the few areas in Brazil that have been monitored for $>20$ years, results indicate that populations in some localities appear to be recovering and exhibiting positive trends, whereas others are declining. The general trend for the species, based on cumulative reports from resource managers working across the species' range, is believed to be a decline compared to historical abundances. However, because only a few basins have been monitored for a sufficiently long period, it is difficult to evaluate the species' global population status and whether it is recovering as a result of conservation interventions. The database compiled here serves as a starting point for developing a regional monitoring programme. Brazil is already implementing a comprehensive national monitoring system for turtles (IBAMA, 2016), and we recommend a simpler version to be implemented internationally, recording basic information over time, including number of nesting females, reproductive output, and human consumption.

It could seem that $>147,000$ nesting females of $P$. expansa managed across the Amazon and Orinoco Basins is 

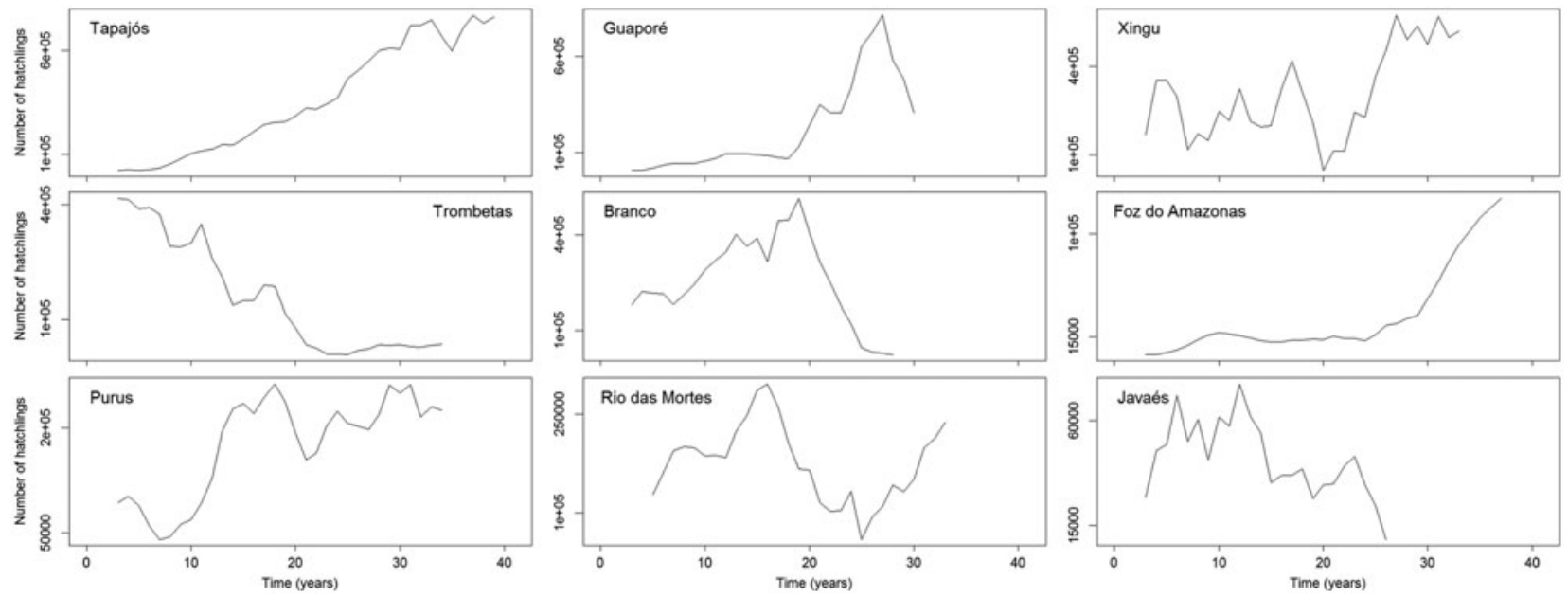

FIG. 2 Population trends of $P$. expansa in nine rivers monitored in Brazil (presented as simple moving average of orders 3-5).

Source: IBAMA, 2016.

TABLE 2 Linear regression results for number of $P$. expansa hatchlings over time in nine river basins monitored in Brazil. Results with a slope significantly different from zero are denoted with ${ }^{*}$, negative and positive coefficients indicate negative and positive trends over time, respectively.

\begin{tabular}{|c|c|c|c|c|c|c|}
\hline River & Estimate $(\beta)$ & SE & $t$ & $\mathrm{P}$ & df & $R^{2}$ \\
\hline Tapajós* & 0.09 & 0.01 & 11.75 & $<0.001$ & 37 & 0.79 \\
\hline Guaporé* & 0.13 & 0.01 & 9.23 & $<0.001$ & 28 & 0.75 \\
\hline Xingu & 0.04 & 0.02 & 1.59 & 0.123 & 28 & 0.08 \\
\hline Trombetas ${ }^{\star}$ & -0.13 & 0.02 & -8.09 & $<0.001$ & 28 & 0.70 \\
\hline Rio Branco ${ }^{\star}$ & -0.07 & 0.02 & -3.14 & $<0.01$ & 26 & 0.27 \\
\hline Foz do Amazonas & 0.16 & 0.03 & 4.64 & $<0.001$ & 26 & 0.45 \\
\hline Purus ${ }^{\star}$ & 0.05 & 0.01 & 4.76 & $<0.001$ & 26 & 0.47 \\
\hline Rio das Mortes & -0.04 & 0.03 & -1.48 & 0.150 & 26 & 0.08 \\
\hline Javaés* & -0.04 & 0.02 & -2.38 & 0.025 & 24 & 0.19 \\
\hline
\end{tabular}

a large number. However, these numbers are dwarfed by historical accounts of the number of turtles harvested. During 1848-1859, 48 million eggs were exported annually from the upper Amazon and the Madeira (Bates, 1892). This corresponds to c. 400,00o females (Bates, 1892), three times the current global protected population. And although the Amazon and Orinoco Basins are vast areas with expansive river systems, where enforcement and monitoring can seem unmanageable, the 89 protected sites described here harbour an important portion of the population of $P$. expansa. The top six sites alone (five in Brazil and one in Bolivia) account for $>100,000$ nesting females. Ensuring long-term protection of the top sites in Brazil and at least the largest population in each of the other countries would secure more than two-thirds of the protected population.

Abundance patterns of the studied turtle populations did not correlate with variables representing human use, such as human population density or nesting beach distance to human settlements. Rather, there is a strong latitudinal pattern in abundance, with more females nesting per locality at lower latitudes. This pattern may be associated with the strong currents and presence of rapids in most of the tributaries that flow north to south. We did not detect an effect of human use on present abundance patterns. However, it is possible that the variables used as measures of human use do not adequately represent actual harvesting levels, or that captured individuals are transported over long distances. There are studies from the Guaporé River that demonstrate an effect of human use on abundance patterns and size distribution at a more localized scale (Conway-Gómez, 2007; Lipman, 2008). Professional poachers may not be local to the area in which they operate, and turtles are shipped to the largest cities in the Amazon (Belém and Manaus), so our approach may not be suitable to determine whether or not human use affects turtle populations at these sites at the scale of this study.

One of the most commonly used methods used to increase natural populations of $P$. expansa is nest relocation (Jaffé et al., 2008). Long-term monitoring projects have shown that when all technical guidelines are followed, there is no reduction in hatching rate, and no difference in 
TABLE 3 Multiple regression results indicating coefficients and significance level for the influence of latitude, longitude, population density and distance to nearest city (by river) on the number of nesting females.

\begin{tabular}{|c|c|c|c|c|}
\hline Variable & Estimate $(\beta)$ & SE & $t$ & $\mathrm{P}$ \\
\hline \multicolumn{5}{|l|}{ All countries } \\
\hline Latitude & $-2.94 \mathrm{E}-06$ & $7.04 \mathrm{E}-07$ & -4.182 & $7.58 \mathrm{E}-05$ \\
\hline Longitude & $-4.69 \mathrm{E}-09$ & $2.82 \mathrm{E}-07$ & -0.017 & 0.9868 \\
\hline Human population density & $-7.97 \mathrm{E}-02$ & $6.73 \mathrm{E}-02$ & -1.185 & 0.2398 \\
\hline Distance to city & $-9.62 \mathrm{E}-09$ & $5.77 \mathrm{E}-09$ & -1.669 & 0.0992 \\
\hline \multicolumn{5}{|l|}{ Brazil only } \\
\hline Latitude & $-2.35 \mathrm{E}-06$ & $8.02 \mathrm{E}-07$ & -2.94 & 0.0046 \\
\hline Longitude & $6.15 \mathrm{E}-07$ & $4.82 \mathrm{E}-07$ & 1.28 & 0.2063 \\
\hline Human population density & $-2.43 \mathrm{E}-04$ & $2.32 \mathrm{E}-04$ & -1.05 & 0.2992 \\
\hline Municipality population & $-4.23 \mathrm{E}-05$ & $3.89 \mathrm{E}-05$ & -1.09 & 0.2812 \\
\hline Municipality GDP ${ }^{1}$ & $-8.68 \mathrm{E}-07$ & $4.94 \mathrm{E}-06$ & -0.18 & 0.8612 \\
\hline Distance to city & $-6.86 \mathrm{E}-06$ & $9.70 \mathrm{E}-06$ & -0.71 & 0.4819 \\
\hline
\end{tabular}

${ }^{1} \mathrm{GDP}$, gross domestic product.

sex ratio, growth rate, and motor skills of hatchlings between natural nests and translocated nests (Hernandez \& Espin, 2006; Andrade, 2015). On the other hand, some research indicates that clutch relocation can affect the embryos and hatchlings in several ways: increasing post-hatching mortality and the incidence of morphological abnormalities (Jaffé et al., 2008), shifting sex ratio of hatchlings in species with temperature-dependent sex determination (Valenzuela \& Ceballos, 2012), and reducing physical condition of hatchlings (Remor de Souza \& Vogt, 1994; Jaffé et al., 2008). Thus, we recommend nest relocation only as a management option of last resort, in cases where reproduction would otherwise be severely compromised. Such situations could include changes in flooding dynamics caused by dams, or particularly high human pressure on turtle populations.

The most commonly used form of hatchling management, head-starting, is also one of the most controversial practices in river turtle conservation. Some authors have documented negative effects of keeping hatchlings in captivity: nutritional deficits (Snyder et al., 1996; Seigel \& Dodd, 2000; Boede \& Hernández, 2004) and increased probability of illnesses caused by viruses, bacteria and parasites (Seigel \& Dodd, 2000; Boede \& Hernández, 2004). Additionally, head-starting may interrupt a vital part of the turtles' life cycle, as posthatching parental care has been reported for this species (Ferrara et al., 2013). Studies using population models and elasticity analyses show that the survival of river turtle populations is affected more by the survival rates of adults and subadults than that of hatchlings and yearlings (Mogollones et al., 2010; Páez et al., 2015). Therefore, and considering the potential negative effects of head-starting, we recommend that turtle conservation programmes focus on in situ conservation strategies such as protecting nesting beaches and reducing the hunting of adult female turtles.

Although there are many initiatives for the conservation of $P$. expansa, few outside Brazil are monitoring populations to assess the effectiveness of their actions. It is possible that continued harvest for illegal trade and habitat destruction are surpassing the effects of conservation efforts (Klemens, 2000), as in some sites the loss of adults has exceeded recruitment. The Reserva Biológica do Rio Trombetas, which once harboured one of the largest populations of $P$. expansa in Brazil, had c. 6,500 nesting females in the 1960 s and 1970s (Zwink \& Young, 1990). The population now consists of $<600$ females (Fig. 2). Knowledge of demographic variables and parameters such as population size and structure, and age-specific survivorship, is essential for evaluating trends and determining a species' conservation status. Monitoring and research that collects these data should thus be prioritized by organizations that lead turtle conservation programmes. In cases where it is not possible to capture turtles (because of local beliefs or restrictions) or when recapture probability is very low, at least the total number of nests and their survival probabilities should be assessed. This includes monitoring the same beaches during the entire reproductive season every year, to document potential changes in the reproductive population.

Current conservation actions may not be sufficient to prevent population declines going forward. In Brazil, the government plans to build an additional 277 hydroelectric dams in the Amazon Basin (Castello et al., 2013). These could be a significant threat for $P$. expansa and other river turtles, flooding their nesting sites and feeding grounds, or isolating them from nesting beaches (Pezzuti et al., 2016). Knowledge of how populations of $P$. expansa are currently being affected by human activities and how they are responding to conservation measures is still limited. Only through long-term monitoring of populations across the species' range will it be possible to predict future persistence of the species and inform broad-scale conservation action. Podocnemis expansa has a large home range and migrates over hundreds of kilometres (Pezzuti et al., 2008; Andrade, 2015), which necessitates conservation actions at a broad geographical 
scale. A collaborative effort across nations to develop protected areas and monitor the species across both the Amazon and Orinoco Basins is essential for the survival of this species.

Acknowledgements We wish to thank Eletrobrás and ICMBio, and Stella Maris Lazarine, José Ribamar da Silva Pinto, Gilmar Klein and Carlos César Durigan for their suggestions and help with the logistics of the workshop. The workshop was funded by the Turtle Conservation Fund, The Mohamed bin Zayed Species Conservation Fund, Wildlife Conservation Society, Turtle Survival Alliance, IUCN/SpSC Tortoise and Freshwater Turtle Specialist Group, and the Instituto Nacional de Pesquisas da Brazil.

Author contributions Study design: GFM, CRF, RCV, RAMB, PCMA, RL, RB; fieldwork and data collection: all authors; statistical analyses, mapping, figures and tables: GFM, CRF, CKF; writing and revisions: all authors.

\section{Conflicts of interest None.}

Ethical standards This work complies with the Oryx ethical guidelines and did not involve research on human subjects or experimentation with animals.

\section{References}

Andrade, P.C.M. (2015) Manejo Comunitário de Quelônios (Família Podocnemididae-Podocnemis unifilis, P. sextuberculata, P. expansa, P. erythrocephala) no Médio Rio Amazonas e Juruá. $\mathrm{PhD}$ thesis, Instituto Nacional de Pesquisas da Amazônia, Manaus, Brazil.

B ates, H.W. (1892) The Naturalist on the River Amazon. John Murray, London, UK.

Boede, E.O. \& Hernández, O. (2004) Diseases in Arrau sideneck turtles, Podocnemis expansa, kept in Venezuelan farms. Revista Científica, 14, 395-403.

BURKe, R.L. (2015) Head-starting turtles: learning from experience. Herpetological Conservation and Biology, 10 (Symposium), 299-308.

Castello, L., McGrath, D.G., Hess, L.L., Coe, M.T., Lefebvre, P.A., Petry, P. et al. (2013) The vulnerability of Amazon freshwater ecosystems. Conservation Letters, 6, 217-229.

Conway-Gómez, K. (2007) Effects of human settlements on abundance of Podocnemis unifilis and P. expansa turtles in northeastern Bolivia. Chelonian Conservation and Biology, $6,199-205$.

Ferrara, C.R., Vogt, R.C. \& Sousa-Lima, R.S. (2013) Turtle vocalizations as the first evidence of posthatching parental care in chelonians. Journal of Comparative Psychology, 127, 24-32.

Hernandez, O. \& Espin, R. (2006) Efectos del reforzamiento sobre la población de tortuga arrau (Podocnemis expansa) en el Orinoco medio, Venezuela. Interciencia, 31, 424-430.

Humboldt, A.V. (1820) Voyages aux Régions Équinoxiales $d u$ Nouveau Continent Fait en 1799-1804 par A. Humboldt et A. Bonpland. Tomo VI. Chez N. Maze, Paris, France.

ibama-Instituto Brasileiro do Meio Ambiente e dos Recursos Naturais Renováveis (2016) Manejo Conservacionista e Monitoramento Populacional de Quelônios Amazônicos. IBAMA, Brasília, Brazil.

ibGE-Instituto Brasileiro de Geografia e Estatística (2010) Populações (dados vetoriais). Http://www.ibge.gov.br [accessed 15 October 2017].
Jaffé, R., Penaloza, C. \& Barreto, G.R. (2008) Monitoring an Endangered freshwater turtle management program: effects of nest relocation on growth and locomotive performance of the giant South American turtle (Podocnemis expansa, Podocnemididae). Chelonian Conservation and Biology, 7, 213-222.

Klemens, M.W. (2000) Turtle Conservation. Smithsonian Institution Press, Washington, DC, USA.

Klemens, M.W. \& Thorbjarnarson, J.B. (1995) Reptiles as a food resource. Biodiversity and Conservation, 4, 281-298.

Lipman, A. (2008) An ecological approach to community-based conservation: management of Podocnemis river turtles in Noel Kempff Mercado National Park, Bolivia. PhD thesis, University of Georgia, Athens, USA.

Lovich, J.E., Ennen, J.R., Agha, M. \& Gibbons, J.W. (2018) Where have all the turtles gone, and why does it matter? Bioscience, 28, $771-781$.

Marcoy, P. (1873) A Journey across South America, from the Pacific Ocean to the Atlantic Ocean. Volume 2. Tumbuya. Sarayacu. Tierra Blanca. Nauta. Tabatinga. Santa Maria de Belen. [Translated from French by E. Rich] Blackie \& Son, London, UK.

Minamb-Ministerio de Medio Ambiente (2002) Reportes Sobre Biología y Manejo de la Podocnemis expansa entre los Años 1990 y 2002. Ministerio del Poder Popular para el Ambiente, Caracas, Venezuela.

Moll, D. \& Moll, E.O. (2004) The Ecology, Exploitation, and Conservation of River Turtles. Oxford University Press, Oxford, UK.

Mogollones, S.C., Rodriguez, D.J., Hernandez, O. \& Barreto, G.R. (2010) A demographic study of the Arrau Turtle (Podocnemis expansa) in the Middle Orinoco River, Venezuela. Chelonian Conservation Biology, 9, 79-89.

Ojasti, J. (1967) Consideraciones sobre la ecologia y conservación de la tortuga Podocnemis expansa (Chelonia, Pelomedusidae). Atas Simposio Sobre Biota Amazônica, 7, 201-206.

Páez, V.P., Bock, B.C., Espinal-García, P.A., Rendón-Valencia, B.H., Alzate-Estrada, D., Cartagena-Otálvaro, V.M. \& HeP PELL, S.S. (2015) Life history and demographic characteristics of the Magdalena River Turtle (Podocnemis lewyana): implications for management. Copeia, 103, 1058-1074.

Pantoja-Lima, J., Aride, P.H.R., de Oliveira, A.T., Félix-Silva, D., Pezzuti, J.C.B. \& RebêLo, G.H. (2014) Chain of commercialization of Podocnemis spp. turtles (Testudines: Podocnemididae) in the Purus River, Amazon Basin, Brazil: current status and perspectives. Journal of Ethnobiology and Ethnomedicine, 10:8.

Peñaloza, C.L., Hernández, O., Espín, R., Crowder, L.B. \& BARReto, G.R. (2013) Harvest of Endangered sideneck river turtles (Podocnemis spp.) in the Middle Orinoco, Venezuela. Copeia, 2013, 111-120.

Peres, C.A. (2000) Effects of subsistence hunting on vertebrate community structure in Amazonian forests. Conservation Biology, $14,240-253$.

Pezzuti, J.C.B., Teixeira, A.S., Silva, D.F., Lima, J.P., Kemenes, A., Garcia, M. et al. (2008) Ecologia de quelônios pelomedusideos na reserva biológica do abufari. In Criação E Manejo de Quelônios no Amazonas (ed. P.C.M. Andrade), pp. 127-173. Pró Várzea/ FAPEAM/SDS, Manaus, Brazil.

Pezzuti, J.C.B., Vidal, M.D. \& Felix-Silva, D. (2016) Impactos da construção de usinas hidrelétricas sobre quelônios aquáticos amazônicos: um olhar sobre o complexo hidrelétrico do Tapajós. In Ocekadi Hidroelétricas, Conflitos Socioambientais e Resistência na Bacia do Tapajós (eds D.F. Alarcon, B. Millican \& M. Torres), pp. 455-478. Câmara Brasileira do Livro. São Paulo, Brazil.

Portelinha, T.C., Malvasio, A., Piña, C.I. \& Bertoluci, J. (2014) Population structure of Podocnemis expansa (Testudines: 
Podocnemididae) in Southern Brazilian Amazon. Copeia, 2014, 707-716.

Remor De Souza, R. \& Vogt, R.C. (1994) Incubation temperature influences sex and hatchling size in the neotropical turtle Podocnemis unifilis. Journal of Herpetology, 28, 453-464.

SEIGEL, R.A. \& DodD, JR, C.K. (200o) Manipulation of turtle populations for conservation: halfway technologies or viable options? In Turtle Conservation (ed. M.W. Klemens), pp. 218-238. Smithsonian Institution Press, Washington, DC, USA.

Smith, N.J. (1974) Destructive exploitation of the South American river turtle. Yearbook of the Pacific Coast Geographers, 36, 85-102.

Sмiтн, N.J.H. (1979) Aquatic turtles of Amazonia: An endangered resource. Biological Conservation, 16, 165-176.

Snyder, N.F.R., Derrickson, S.R., Beissinger, S.R., Wiley, J.W., Smith, T.B., Toone, W.D. \& Miller, B. (1996) Limitations of captive breeding in endangered species recovery. Conservation Biology, 10, 338-348.

Tortoise \& Freshwater Turtle Specialist Group (1996) Podocnemis expansa (errata version published in 2016). In The IUCN Red List of Threatened Species 1996: e.T17822A97397263. Https://www.iucnredlist.org/species/17822/97397263 [accessed 31 October 2018].

Turtle Taxonomy Working Group (Rhodin, A.G.J., Iverson, J.B., Bour, R., Fritz, U., Georges, A., Shaffer, H.B. \&van DijK,
P.P.) (2017) Turtles of the world: annotated checklist and atlas of taxonomy, synonymy, distribution, and conservation status. In Conservation Biology of Freshwater Turtles and Tortoises: a Compilation Project of the IUCN/SSC Tortoise and Freshwater Turtle Specialist Group. 8th edition. Chelonian Research Monographs, Volume 7 (eds A.G.J. Rhodin, J.B. Iverson, P.P. van Dijk, R.A. Saumure, K.A. Buhlmann, P.H.C. Pritchard, and R.A. Mittermeier), pp. 1-292. Chelonian Research Foundation, Lunenburg, USA and Turtle Conservancy, New York, USA.

Valenzuela, N. \& Ceballos, C.P. (2012) Evolución y mecanismos de determinación sexual en tortugas. In V. Biología y Conservación de las Tortugas Continentales de Colombia. Serie Editorial Recursos Hidrobiológicos y Pesqueros Continentales de Colombia (eds V.P. Páez, M.A. Morales-Betancourt, C.A. Lasso, O.V. Castaño-Mora \& B.C. Bock), pp. 115-123. Instituto de Investigación de Recursos Biológicos Alexander von Humboldt, Bogotá, Colombia.

Vogt, R.C. (2008) Amazon Turtles. Wust Ediciones, Bíblios, Lima, Peru.

WorldPop (2010) WorldPop v.1.o. Https://www.worldpop.org/ geodata/listing? $\mathrm{id}=17$ [accessed 3 October 2018].

Zwink, W. \& Young, P.S. (1990) Desova e eclosão de Podocnemis expansa (Schweigger, 1812) (Chelonia: Pelomedusidae) no Rio Trombetas, Pará, Brasil. Forest, 90, 34-35. 